\title{
PENGARUH PELAKSANAAN KINERJA PENGAWAS PAI DAN KEPALA SEKOLAH TERHADAP PROFESIONALITAS GURU PAI DI SMP NEGERI 1 PAREPARE
}

\author{
Andi Syamsul \\ SMPN 1 Kota Parepare \\ Email:andisyamsul160116@gmail.com
}

\begin{abstract}
This article aims to discuss the implementation of the supervisory duties of the PAI, the performance of principals, the professionalism of PAI teachers, and the contribution of supervisors and principals to the professionalism of PAI teachers in SMP Negeri 1 Parepare. This type of research is applied research that is correlational or associative. The PAI surveillance population, the principals of one person and the PAI teacher are four. Sampling technique used is saturated sample technique or total sampling that is the determination and sampling taken as a whole as many as 6 people. The results show that the implementation of PAI supervisors in SMPN 1 Parepare is very high. The performance of principals is categorized as either high or good. The professional level of teachers of PAI is categorized as high, strong or good professionalism of the teacher. As for the supervisors of PAI and principals there is a very significant influence on the professionalism of PAI teachers in SMP Negeri 1 Parepare.
\end{abstract}

Keywords: Supervisory, Principals, Teacher, Profesionalism

\begin{abstract}
ABSTRAK
Artikel ini bertujuan membahas pelaksanaan tupoksi pengawas PAI, kinerja kepala sekolah, profesionalitas guru PAI, dan kontribusi pengawas dan kepala sekolah terhadap profesionalitas guru PAI di SMP Negeri 1 Parepare.Jenis penelitian ini adalah penelitian terapan yang bersifat studi korelasional atau asosiatif.Populasi pengawas PAI, kepala sekolah masing-masing satu orang dan guru PAI adalah empat orang. Teknik pengambilan sampel yang digunakan adalah teknik sampel jenuh atau total sampling yaitu penentuan dan pengambilan sampel dilakukan secara keseluruhan sebanyak 6 orang. Hasil penelitian menunjukkan bahwa pelaksanaan pengawas PAI di SMPN 1 Parepare adalah sangat tinggi.Kinerja kepala sekolah digolongkan ke dalam kategori tinggi atau baik.Tingkat profesionalitas guru PAI tergolong kategori tinggi, kuat atau baik profesionalitas
\end{abstract}


gurunya.Adapun pengawas PAI dan kepala sekolah terdapat pengaruh yang sangat signifikan terhadap profesionalitas guru PAI di SMP Negeri 1 Parepare Kata Kunci: Pengawas, Kepala Sekolah, Guru, Profesionalitas

\section{PENDAHULUAN}

Pengawasan merupakan kegiatan yang membantu memperbaiki dan meningkatkan dalam pengelolaan PAI di Sekolah dan Madrasah dengan tujuan agar tercipta kondisi kegiatan pembelajaran yang baik. Dalam melakuakan pengawasan, pengawas PAI pada sekolah umum terdapat dua macam pengawas mata pelajaran PAI pada TK, SD, SLB serta pengawas sekolah mata pelajaran Agama Islam SLTP, SMU, dan SMK.

Implementasi pelaksanaan pengawasan PAI pada sekolah umum baik pada bidang akademik, pendidikan dan pengajaran, kurikulum, pemantauan faktor pendukung dalam pelaksanaannya maupun bidang monitoring kegiatan pembelajaran. Apabila fungsi pengawas tersebut dilakukan secara efektif, maka kualitas pendidikan akan meningkat dan mencapai tujuan pendidikan, baik tujuan pendidikan nasional, institusional, kurikuler, maupun tujuan instruksional.

Gambaran teori tersebut di atas ingin menguji tingkat kontribusi pengawas PAI dan Kinerja Kepala Sekolah terhadap profesionalitas guru PAI.Dari hasil observasi awal ditemukan dan diasumsikan bahwa pengawas pendidikan dan kinerja guru belum maksimal memberikan kontribusi positif terhadap tingkat profesionalitas guru PAI sehingga penelitian ini sangat urgen untuk dikaji.

Pada implementasi fungsi manajerial, pengawas memberikan kontribusi besar terhadap kinerja kepala sekolah dan lebih-lebih terhadap tenaga kependidikan sehingga dapat menjamin tingkat profesionalitas sumber daya pada setiap lembaga pendidikan.

Sesuai dengan variabel penelitian sebagai fokus analisis, maka masalah penelitian ini dapat diidentifikasi sebagai berikut:

1. Pelaksanaan tupoksi pengawas PAI di SMP Negeri 1 Parepare

2. Tingkat kinerja kepala sekolah di SMP Negeri 1 Parepare

3. Tingkat profesionalitas guru PAI di SMP Negeri 1 Parepare

4. Kontribusi pengawas PAI dan kinerja kepala sekolah terhadap tingkat profesionalitas guru PAI di SMP Negeri 1 Parepare.

\section{Rumusan Masalah}

Berdasarkan latar belakang dan variabel-variabel penelitian, maka dapat dirumuskan masalah penelitiannya yaitu:

1. Bagaimana pelaksanaan tupoksi pengawas PAI di SMP Negeri 1 Parepare? 
2. Bagaimana tingkat kinerja kepala sekolah di SMP Negeri 1 Parepare?

3. Bagaimana tingkat profesionalitas guru PAI di SMP Negeri 1 Parepare?

4. Apakah pengawas PAI dan kinerja kepala sekolah berkontribusi positif terhadap tingkat profesionalitas guru PAI di SMP Negeri 1 Parepare?

\section{Definisi Operasional dan Ruang Lingkup Penelitian}

Definisi operasional variabel dirumuskan berdasarkan variabel-variabel penelitian; variabel penelitian ini terdiri atas:

1. Pengawas PAI yang dimaksudkan adalah pegawai negeri sipil yang diangkat dan diberi tugas, tanggung jawab, dan wewenang untuk melakukan pengawasan PAI di Sekolah Menengah Pertama Negeri 1 Parepare.

2. Kinerja Kepala Sekolah yang dimaksudkan adalah hasil kerja yang dicapai oleh seorang kepala sekolah pada lembaga pendidikan Sekolah Menengah Pertama Negeri 1 Parepare, sesuai dengan wewenang dan tanggung jawabnya dalam rangka mencapai tujuan pendidikan

3. Profesionalitas Guru PAI yang dimaksudkan adalah profesi seorang guru PAI yang mempunyai kemampuan pengelolaan kelas, strategi mengajar, menguasai materi, menggunakan media pembelajaran, menyusun program pembelajaran, dan membuat penilaian hasil belajar yang tepat.

\section{Jenis dan Pendekatan Penelitian}

Jenis penelitian ini adalah penelitian terapan yang bersifat studi korelasional atau asosiatif.Sugiyono menyatakan bahwa jenis penelitian asosiatif dipergunakan untuk mengukur tingkat hubungan antarvariabel yaitu variabel independen dan variabel dependen. ${ }^{1}$

Penelitian ini apabila ditinjau dari jenis datanya tergolong kategori penelitian kuantitatif yang ingin mengumpulkan dan menganalisis data dengan menggunakan angka-angka.Angka-angka tersebut diperoleh dari penyebaran instrument angket yang telah disusun oleh peneliti.

\section{Waktu dan Lokasi Penelitian}

Penelitian ini dilakukan selama tiga bulan pada Sekolah Menengah Pertama Negeri 1 Parepare.Sasaran utama pada penelitian ini adalah pengawas PAI, Kinerja Kepala Sekolah dan Profesionalitas Guru PAI.Pada bulan pertama dipergunakan untuk menyusun proposal penelitian sampai ujian proposal.Pada bulan kedua

\footnotetext{
4.

${ }^{1}$ Sugiyono, Metode Penelitian Kualitatif, Kuantitatif, $R$ \& D (Cet. I; Bandung: Alfabeta, 2012), h. 
dipergunakan untuk menyusun instrumen dan mengumpulkan data penelitian.Pada bulan ketiga dipergunakan untuk mengolah dan menganalisis data sampai menemukan hasil penelitian yang objektif, valid, dan dapat dipertanggungjawabkan.Lokasi penelitian ini dilakukan di SMP Negeri 1 Parepare.

\section{Desain Variabel Penelitian}

Penelitian ini terdiri atas dua variabel, yaitu variabel berpengaruh (independent variable) dan variabel terpengaruh (dependent variable).Variabel yang tergolong kategori variabel independent adalah "Pengawas PAI" yang ditandai dengan simbol X1 dan "Kinerja Kepala Sekolah" yang ditandai dengan simbol X2.Pada variabel dependent adalah "Profesionalitas Guru PAI" yang ditandai dengan simbol $\mathbf{Y}$. demikian halnya pengungkapan seberapa besar kontribusi antara variabel $\mathrm{X}_{1}{ }^{\mathrm{r} 1}$ dan $\mathrm{X}_{2}{ }^{\mathrm{r} 2}$ secara bersama-sama $\left(\mathrm{r}_{3}\right)$ terhadap variabel Y.

Desain hubungan desain paradigma antarvariabel penelitian ini dapat digambarkan sebagai berikut:

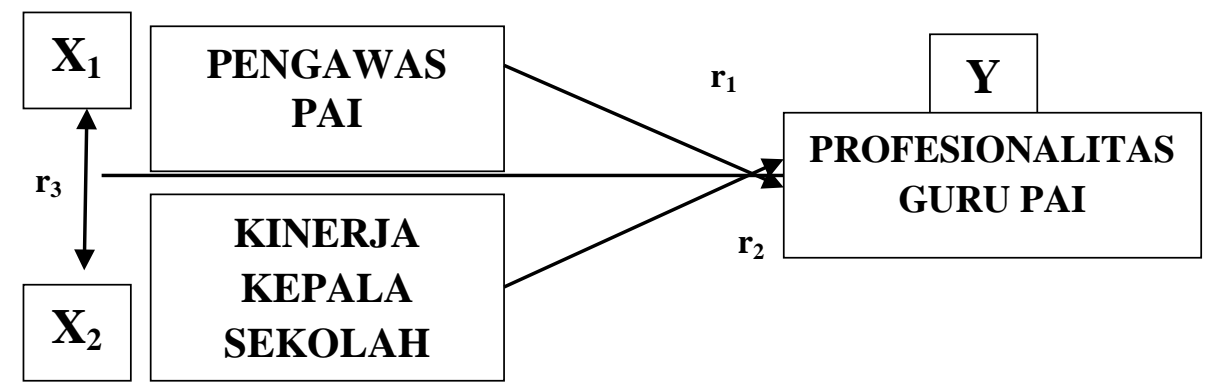

Gambar desain variabel di atas menunjukkan simbol $\mathrm{X}_{1}, \mathrm{X}_{2}$, dan $\mathrm{Y}$ akan di analisis dengan menggunakan uji deskriptif. Simbol $r_{1}$ dan $r_{2}$ akan diuji dengan menggunakan uji korelasi, dan simbol $r_{3}$ akan diuji dengan menggunakan uji regresi linier berganda.

\section{Populasi dan Sampel}

Populasi pada umumnya berarti keseluruhan objek penelitian, mencakup semua elemen yang terdapat dalam wilayah penelitian.Tashakkori Abbas mengemukakan bahwa populasi meliputi semua individu yang menjadi sumber pengambilan sampel. ${ }^{2}$ Populasi merupakan wilayah generalisasi yang terdiri atas

\footnotetext{
${ }^{2}$ Tashakkori Abbas, Mixed Methods: in Social and Behavioral Research (Yokyakarta: Pustaka Pelajar, 2010,) h. 79.
} 
objek/subjek yang mempunyai kuantitas dan karakteristik tertentu yang ditetapkan oleh peneliti untuk dipelajari dan kemudian ditarik kesimpulannya.Sugiyono mengemukakan bahwa populasi adalah seluruh data yang menjadi perhatian kita dalam suatu ruang lingkup dan waktu yang ditentukan. ${ }^{3}$

Populasi pengawas PAI pada tingkat Sekolah Menengah Pertama Kota Parepare dan kepala sekolah masing-masing terdiri atas satu orang.Sedangkan keadaan populasi guru PAI pada objek penelitian ini terdiri atas empat orang guru PAI.

Sampel adalah bagian dari jumlah dan karakteristik yang dimiliki oleh populasi. ${ }^{4}$ Pengambilan sampel pengawas PAI, kepala sekolah, dan guru PAI dilakukan dengan teknik sampel jenuh atau total sampling yaitu penentuan dan pengambilan sampel dilakukan secara keseluruhan. Sampel pengawas PAI terdiri atas 1 orang pengawas, 1 kepala sekolah, dan 4 guru PAI di SMP Negeri 1 Parepare.Dengan demikian, jumlah sampel secara keseluruhan sebanyak 6 orang.

\section{Instrumen Penelitian}

Pernyataan pada variabel independen dan variabel dependen diungkapkan dalam tingkatan pilihan gradasi yang diberikan bobot pada angket yang disebarkan dan telah dijawab oleh responden (lihat lampiran). Pernyataan dan pembobotan, sebagaimana dalam tabel dua di bawah ini:

Tabel Instrumen Penelitian

\begin{tabular}{|l|c|l|c|}
\hline \multicolumn{1}{|c|}{$\begin{array}{c}\text { Pernyataan Positif } \\
\text { Variabel } \mathrm{X}_{1}, \text { X2, dan Y }\end{array}$} & $\begin{array}{c}\text { Bobot } \\
\text { Skor }\end{array}$ & $\begin{array}{c}\text { Pernyataan Negatif } \\
\text { Variabel } \mathrm{X}_{1}, \mathrm{X} 2 \text {, dan Y }\end{array}$ & $\begin{array}{c}\text { Bobot } \\
\text { Skor }\end{array}$ \\
\hline Sangat Setuju (SS) & 5 & Sangat Setuju (SS) & 1 \\
Setuju (S) & 4 & Setuju (S) & 2 \\
Ragu/Netral (R/N) & 3 & Ragu/Netral (R/N) & 3 \\
Tidak Setuju (ST) & 2 & Tidak Setuju (ST) & 4 \\
Sangat Tidak Setuju (STS) & 1 & Sangat Tidak Setuju (STS) & 5 \\
& & & \\
\hline
\end{tabular}

\footnotetext{
${ }^{3}$ Sugiyono, Metode Penelitian Kualitatif, Kuantitatif, $R$ \& D (Cet. I; Bandung: Alfabeta. 2012), h. 119. 62.

${ }^{4}$ Sugiyono, Metode Penelitian Kualitatif, Kuantitatif, $R$ \& D (Cet. I; Bandung: Alfabeta, 2012), h.
} 


\section{Uji Validitas dan Reliabilitas Instrumen}

Kriteria pokok yang harus dipenuhi oleh suatu instrumen penelitian agar dapat dinyatakan memiliki kualitas baik adalah validitas, reliabilitas dan praktibilitas. ${ }^{5}$

\section{Teknik Pengumpulan Data}

Teknik pengumpulan data sebagai instrumen penelitian yang dipergunakan dalam tesis ini terdiri atas: teknik observasi, dokumentasi, wawancara, dan teknik quisioner.

\section{Teknik Pengolahan dan Analisis Data}

Data yang diperoleh dari hasil penelitian diolah dan dianalisis dengan menggunakan analisis statistik deskriptif, asosiatif dengan korelasi pearson product moment dan regresi linier berganda.

\section{PEMBAHASAN}

Gambaran Tingkat Pelaksanaan Kinerja Pengawas PAI di SMP Negeri 1 Parepare

Data hasil penelitian tingkat pelaksanaan kinerja pengawas PAI SMP Negeri 1 Parepare mendapatkan nilai maksimun sebesar 100,00 dan nilai minimum diperoleh sebesar 68,00 dengan nilai rata-rata (mean) sebesar 90,667. Nilai tersebut apabila dipetakan ke dalam interval nilai distribusi frekuensi tunggal dan distribusi frekuensi bergolong secara perhitungan statistik deskriptif berada dalam kategori sangat baik/sangat tinggi/sangat kuat.

\section{Kinerja Kepala Sekolah di SMP Negeri 1 Parepare}

Data hasil penelitian tingkat kinerja kepala sekolah di SMP Negeri 1 Parepare mendapatkan nilai maksimun sebesar 105,00 dan nilai minimum diperoleh sebesar 88,00 dengan nilai rata-rata (mean) sebesar 97,500. Nilai tersebut apabila dipetakan ke dalam interval nilai distribusi frekuensi tunggal dan distribusi frekuensi bergolong secara perhitungan statistik deskriptif berada dalam kategori tinggi/kuat/baik.

\footnotetext{
${ }^{5}$ Riduwan dan Sunarto, Pengantar Statistika untuk Penelitian: Pendidikan, Sosial, Ekonomi, Komunikasi, dan Bisnis (Cet. IV; Bandung: Alfabeta, 2011), h. 348.
} 


\section{Profesionalitas Guru PAI di SMP Negeri 1 Parepare}

Data hasil penelitian tingkat profesionalitas guru PAI di SMP Negeri 1 Parepare mendapatkan nilai maksimun sebesar 98,00 dan nilai minimum diperoleh sebesar 88,00 dengan nilai rata-rata (mean) sebesar 93,167. Nilai tersebut apabila dipetakan ke dalam interval nilai distribusi frekuensi tunggal dan distribusi frekuensi bergolong secara perhitungan statistik deskriptif berada dalam kategori tinggi/kuat/baik.

\section{PengaruhKinerja Pengawas PAI terhadap Kinerja Kepala Sekolah di SMP Negeri 1 Parepare}

Hasil perhitungan analisis corelation bivariate product moment yang dikenal dengan Correlation Pearsons diperoleh hubungan atau korelasi pelaksanaan kinerja pengawas PAI terhadap tingkat kinerja Kepala Sekolah di SMP Negeri 1 Parepare sebesar 0,925. Apabila nilai ini dimasukkan ke dalam skala pengukuran interpretasi data indeks korelasi " $\mathrm{r}_{\mathrm{xy}}$ " product moment, maka tergolong kategori sangat tinggi dengan nilai kontribusi sebesar 85,563\% dan sangat signifikan.

\section{Pengaruh Kinerja Pengawas PAI terhadap Profesionalitas Guru PAI di SMP Negeri 1 Parepare}

Hasil perhitungan analisis corelation bivariate product moment yang dikenal dengan Correlation Pearsons diperoleh hubungan atau kontribusi pelaksanaan kinerja pengawas PAI terhadap tingkat profesionalitas guru PAI di SMP Negeri 1 Parepare sebesar 0,437. Apabila nilai ini dimasukkan ke dalam skala pengukuran interpretasi data indeks korelasi " $\mathrm{r}_{\mathrm{xy}}$ " product moment, maka tergolong kategori cukup tinggi dengan nilai kontribusi sebesar 19,097\% dan signifikan.

\section{Pengaruh Kinerja Kepala Sekolah terhadap Profesionalitas Guru di SMP Negeri 1 Parepare}

Hasil perhitungan analisis corelation bivariate product moment yang dikenal dengan Correlation Pearsons diperoleh hubungan atau korelasi kinerja kepala sekolah terhadap tingkat profesionalitas guru PAI di SMP Negeri 1 Parepare sebesar 0,248. Apabila nilai ini dimasukkan ke dalam skala pengukuran interpretasi data indeks korelasi " $\mathrm{r}_{\mathrm{xy}}$ " product moment, maka tergolong kategori rendah dengan nilai kontribusi sebesar 6,150\% dan tidak signifikan. 


\section{Pengaruh Pelaksanaan Kinerja Pengawas PAI dan Kepala Sekolah terhadap Profesionalitas Guru PAI di SMP Negeri 1 Parepare}

Hasil perhitungan dengan cara manual menghasilkan nilai $\mathrm{R}=0,601$ dapat dibuktikan dengan menggunakan analisis SPSS for windows yang menghasilkan nilai yang sama sebagaimana tabel di bawah ini:

TabelRegresi Linier Berganda Model Summary ${ }^{\mathrm{b}}$ tentang kontribusi Pelaksanaan Kinerja Pengawas PAI dan Kinerja Kepala Sekolah terhadap Profesionalitas Guru

PAI di SMP Negeri 1 Parepare

\begin{tabular}{|c|c|c|c|c|c|c|c|c|c|}
\hline \multirow{3}{*}{$\begin{array}{c}\text { Mode } \\
1\end{array}$} & & & \multirow{2}{*}{$\begin{array}{c}\text { Adjust } \\
\text { R }\end{array}$} & Std. Error & \multicolumn{5}{|c|}{ Change Statistics } \\
\cline { 5 - 10 } & Square & Square & $\begin{array}{c}\text { of the } \\
\text { Estimate }\end{array}$ & $\begin{array}{c}\text { R Square } \\
\text { Change }\end{array}$ & $\begin{array}{c}\text { F } \\
\text { Change }\end{array}$ & df1 & df2 & $\begin{array}{c}\text { Sig. F } \\
\text { Change }\end{array}$ \\
\hline 1 & $\mathbf{0 . 6 0 1}^{2}$ & $\mathbf{0 . 3 6 1}$ & -.065 & 4.25060 & $\mathbf{0 . 3 6 1}$ & $\mathbf{0 . 8 4 8}$ & 2 & 3 & .511 \\
\hline
\end{tabular}

a. Predictors: Kinerja Kepala Sekolah, Pelaksanaan Kinerja Pengawas PAI

b. Dependent variable: Profesionalitas Guru PAI

Hasil perhitungan uji regresi linier berganda diperoleh nilai $\mathrm{R}=0,601$ yang dapat ditafsirkan ke dalam interpretasi dan kategorisasi nilai regresi linier berganda yaitu kontribusi antara Pelaksanaan Kinerja Pengawas PAI dan Kinerja Kepala Sekolah terhadap Profesionalitas Guru PAI di SMP Negeri 1 Parepare tergolong kategori tinggi dengan nilai kontribusi sebesar 36,120\% dan signifikan.

\section{SIMPULAN}

Berdasarkan rumusan masalah, hipotesis, hasil penelitian, dan pembahasan, maka dapat disimpulkan beberapa hal pokok yang berkaitan dengan pengaruh pelaksanaan kinerja pengawas PAI dan kepala sekolah terhadap profesionalitas guru PAI di SMP Negeri 1 Parepare sebagai berikut:

1. Pelaksanaan pengawas PAI di SMP Negeri 1 Parepare yang diuji secara statistik deskriptif baik dengan menggunakan analisis manual maupun analisis SPSS for windows versi 22.00 tergolong kategori sangat tinggi atau sangat baik dengan perolehan nilai skor angka rata-rata atau mean $=90,667$ median atau nilai rata-rata letak nilai sebesar 93,00 yang dapat dikategorikan cukup baik, modus sebesar 91,00 pada rentang nilai sebanyak 32,00. Penyebaran nilai-nilai didapatkan nilai terendah sebanyak 68,00 dan nilai tertinggi sebanyak 100,00, jumlah atau sum nilai skor secara keseluruhan sebanyak 544. 
2. Kinerja kepala sekolah di SMP Negeri 1 Parepare yang diuji dan dianalisis secara statistik deskriptif diperoleh nilai skor angka rata-rata atau mean = 97,500. Secara kualitatif dapat digolongkan ke dalam kategori tinggi atau baik. Angka tersebut menempati nilai rata-rata letak atau median sebesar 98,000 yang dapat dikategorikan tinggi atau baik, modus sebesar 98,000 pada rentang nilai sebanyak 17,00 . Penyebaran nilai-nilai didapatkan nilai terendah sebanyak 88,00 dan nilai tertinggi sebanyak 105,00, jumlah atau sum nilai skor secara keseluruhan sebanyak 585. Apabila dilihat dari jumlah perolehan skor secara keseluruhan, maka kinerja kepala sekolah di SMP Negeri 1 Parepare lebih rendah dibandingkan dengan pelaksanaan tupoksi pengawas PAI.

3. Tingkat profesionalitas guru PAI di SMP Negeri 1 Parepare. Hasil perhitungan berdasarkan instrumen penelitian dengan menggunakan statistik deskriptif baik analisis secara manual maupun dengan sistem komputer diperoleh nilai skor rata-rata mean 93,167 yang ditetapkan dalam skala pengukuran tergolong kategori tinggi, kuat atau baik profesionalitas gurunya.

4. Terdapat pengaruh yang sangat signifikan antara pelaksanaan pengawas PAI terhadap kinerja kepala sekolah di SMP Negeri 1 Parepare sebesar $r_{x 1 \times 2}$ 0,925. Angka ini secara kualitatif tergolong kategori sangat tinggi/sangat kuat dengan nilai kontribusi sebanyak 85,563\%.

Pengaruh pelaksanaan kinerja pengawas PAI terhadap profesionalitas guru diperoleh nilai $r_{x 1 y}=0,437$ yang tergolong kategori cukup tinggi namun tidak signifikan dengan nilai kontribusi sebesar 19,097\%.

Pada uji pengaruh kinerja kepala sekolah terhadap profesionalitas guru PAI diperoleh nilai $r_{x 2 y}=0,248$ yang tergolong kategori rendah dan tidak signifikan dengan nilai kontribusi sebesar 6,150\%.

Pengaruh pelaksanaan kinerja pengawas PAI dan kepala sekolah terhadap tingkat profesionalitas guru PAI di SMP Negeri 1 Parepare tergolong kategori tinggi, kuat, dan baik namun tidak signifikan. Kategori ini dibuktikan oleh hasil penelitian pada nilai skor regresi ganda yang diperoleh nilai skor $\mathrm{R}_{(\mathrm{x} 1 \mathrm{x} 2) \mathrm{y}}=0,601$. Nilai skor ini berada pada garis indeks korelasi yang tergolong kategori tinggi, baik, dan kuat. Kaidah pengujian signifikansi dengan menyandarkan diri pada hasil perhitungan $\mathrm{F}_{\text {hitung }}$ yang dibandingkan dengan $\mathrm{F}_{\text {tabel }}$ diperoleh $\mathrm{F}_{\text {hitung }}=1,814 \leq \mathrm{F}_{\text {tabel }}$ = 9,56 pada taraf signifikansi 0,05\%, maka tergolong kategori tidak signifikan. Demikian pula sumbangan variable kinerja pengawas PAI dan kepala sekolah terhadap tingkat profesionalitas guru PAI di SMP Negeri 1 Parepare hanya 
mendapatkan nilai skor $\mathrm{KP}=36,120 \%$ dan sisanya $63,880 \%$ dipengaruhi oleh variabel lain.

Dengan demikian, hasil penelitian diperoleh bahwa kinerja pengawas PAI dan kepala sekolah secara bersama-sama tidak mampu meningkatkan profesionalitas guru PAI di SMP Negeri 1 Parepare.

\section{DAFTAR PUSTAKA}

Arcaro, Jerome S. 2007. Pendidikan Berbasis Mutu: Prinsip-Prinsip Perumusan dan Tata Langkah Penerapan. Cet. IV; Yokyakarta: Pustaka Pelajar.

Azis, Hamka Abdul. 2012. Karakter Guru Profesional: melahirkan Murid Unggul Menjawab Tantangan Masa Depan. Jakarta: Al Mawardi.

Azzet, Akhmad Muhaimin. 2011. Menjadi Guru Favorit.Cet. I; Jokjakarta: ArRuzz Media.

Barizi, Ahmad. 2009. Menjadi Guru Unggul. Cet. I; Jokjakarta: Ar-Ruzz Media.

Black, James A. 2001. Metode dan Masalah Penelitian Sosial. Cet. III; Bandung: Refika Aditama.

Crosby, Philip B. 1995. Quality Without Tear. New York: McGraw-Hill.

Creswell, Jhon W dan Vicki L. Plano Clark. 2007. Mixed Methods Research.London: Sage Publication.

Danim, Sudarwan. 2011. Pengembangan Profesi Guru.Cet. I; Jakarta: Kencana.

Effendi. 1993. Kurikulum Pendidikan Nasional. Cet. II; Jakarta: Balai Pustaka.

Gudono. 2011. Analisis Multivariat. Cet. I; Yokyakarta: BPFE.

Hasan, Iqbal. 2004. Analisis Data Penelitian dengan Statistik.Cet. I; Jakarta: Bumi Aksara.

Ibrahim, R dan Nanah Syaodih S. 2010. Perencanaan Pengajaran. Cet. III; Jakarta: Rineka Cipta.

Nurkolis. 2003. Manajemen Berbasis Sekolah: Teori, Model dan Aplikasi. Cet. III; Jakarta: Grasindo.

Peraturan Pemerintah Nomor 19 Tahun 2005 tentang Standar Nasional Pendiidkan.

Undang-Undang No. 20 tahun 2003, tentang Sistem Pendidikan Nasional.

Undang-Undang No. 14 tahun 2005, tentang Guru dan Dosen.

Usman, Uzer. 2001. Menjadi Guru Profesional.Cet. XIII; Bandung: PT. Remaja Rosdakarya. 